\title{
Novel Synthesis Method of Micronized Ti-Zeolite Na-A and Cytotoxic Activity of Its Silver Exchanged Form
}

\author{
H. F. Youssef, ${ }^{1}$ W. H. Hegazy, ${ }^{2}$ H. H. Abo-almaged, ${ }^{1}$ and G. T. El-Bassyouni ${ }^{3}$ \\ ${ }^{1}$ Refractories, Ceramics and Building Materials Department, National Research Centre (NRC), Dokki, Cairo 12622, Egypt \\ ${ }^{2}$ Department of Chemistry, Faculty of Science, Suez University, Suez 43533, Egypt \\ ${ }^{3}$ Biomaterials Department, National Research Centre (NRC), Dokki, Cairo 12622, Egypt
}

Correspondence should be addressed to W. H. Hegazy; whchemistry@hotmail.com

Received 26 November 2014; Revised 27 December 2014; Accepted 30 December 2014

Academic Editor: Francesco P. Fanizzi

Copyright (C) 2015 H. F. Youssef et al. This is an open access article distributed under the Creative Commons Attribution License, which permits unrestricted use, distribution, and reproduction in any medium, provided the original work is properly cited.

\begin{abstract}
The core-shell method is used as a novel synthetic process of micronized Ti-Zeolite Na-A which involves calcination at $700^{\circ} \mathrm{C}$ of coated Egyptian Kaolin with titanium tetrachloride in acidic medium as the first step. The produced Ti-coated metakaolinite is subjected to microwave irradiation at low temperature of $80^{\circ} \mathrm{C}$ for $2 \mathrm{~h}$. The prepared micronized Ti-containing Zeolites-A (Ti-ZA) is characterized by FTIR, XRF, XRD, SEM, and EDS elemental analysis. Ag-exchanged form of Ti-Z-Ag is also prepared and characterized. The $\mathrm{Wt} \%$ of silver exchanged onto the Ti-Zeolite structure was determined by atomic absorption spectra. The in vitro cytotoxic activity of Ti-Z-Ag against human hepatocellular carcinoma cell line (HePG2), colon cell line carcinoma (HCT116), lung carcinoma cell line (A549), and human Caucasian breast adenocarcinoma (MCF7) is reported. The results were promising and revealed that the exchanged Ag form of micronized Ti-Zeolite-A can be used as novel antitumor drug.
\end{abstract}

\section{Introduction}

Zeolites are inorganic, crystalline, microporous, and aluminotectosilicates with an open framework (ring structure) of $\mathrm{SiO}_{4}$ and $\mathrm{AlO}_{4}$ tetrahedra, connected via oxygen atoms at their corner points. The three-dimensional structure of Zeolites generates uniformly sized interconnected micropores and channels which form sharply defined, two- or three-dimensional channel systems of molecular dimensions in $0.3-1.4 \mathrm{~nm}$ range where cations, large molecules, and even cationic groups (as water, ammonia, carbonate and nitrate anions, etc.) are present [1]. Water molecules are removable (i.e., sorbed/adsorbed) where alkali cations seem to be exchanged. These channels are identified by its direction relative to the crystallographic axes. The number of either T(Si- and $\mathrm{Al}-$ ) or $\mathrm{O}$-atoms forming the rings controlling the diffusion through the channels and the crystallographic free diameter of the channels, in Angstrom units, is based upon the atomic coordinates of the type of materials and the oxygen radius of $1.35 \AA$ [2].

More than 46 Zeolite minerals are naturally occurring and more than 150 synthetic structures are present in the literature. Synthetic Zeolites are used commercially more than the natural ones due to their purity, degree of crystallinity, and pore-size uniformity [3]. Zeolites are usually prepared from dense gels containing silica and alumina species at elevated temperatures in a relatively expensive process. Thus, the presence of natural resources necessary for their production such as rocks, volcanic tuffs, pumice, and diatomite is a matter of economic interest.

Microwave-assisted-hydrothermal synthesis is a process that is used efficiently for the rapid synthesis of numerous ceramic oxides and porous materials [4-6]. It offers many advantages over the conventional methods, especially for Zeolite synthesis, including quick and uniform heating, homogeneous nucleation, fast dissolution of precipitated gels, and shorter crystallization time. Heating is induced via the friction of molecular motion enhanced by microwave irradiation. Thus, it is possible to heat the reactants selectively and homogeneously. Furthermore, microwave heating is energy saving and economically efficient $[7,8]$.

Zeolite-Na-A is one of the simplest synthetic Zeolites with a molecular ratio of 1:1:1 (Si:Al:Na). Zeolite-Na-A (ZA) 
exhibits the LTA (linde type A) cubic structure $[9,10]$. The unit cell of Zeolite-Na-A consists of $12 \mathrm{SiO}_{2}$ and $12 \mathrm{AlO}_{2}$ units in a structure that conforms a large $(\alpha$-cage $)$ and small $(\beta$ cage) cavity and pore window opening with corresponding diameters of $11.4,6.6$, and $4.1 \AA$, respectively. The chemical composition of unit cell is $\mathrm{Na}_{12}\left[\mathrm{Al}_{12} \mathrm{SiO}_{12} \mathrm{O}_{48}\right] \cdot 27 \mathrm{H}_{2} \mathrm{O}$. The $\alpha$-cage in Zeolite-Na-A accommodates 8 or 12 atoms of the total number of sodium in the unit cell, while only 4 sodium atoms are placed in the $\beta$-cage $[9,10]$. Based on its structure and composition, Zeolite-A has high ionic conductivity and high ion-exchange capacity that facilitate its introduction in various applications such as detergency, desiccation, adsorption, separation, and ion exchange [11].

Properties exhibited by Zeolites are strongly dependent upon the exchangeable cations hosted in their framework. According to the incorporation of the metal ions into their structure, Zeolites can be either ion exchangeable or framework substituted. Introducing foreign atoms other than aluminum in the Zeolite framework structure greatly change their catalytic activity. It is well known that the aluminosilicate framework builders, T-atoms, that is, $\mathrm{Si}$ and $\mathrm{Al}$, can be substituted by other metals such as $\mathrm{Al}^{3+}$ by $\mathrm{B}^{3+}$, $\mathrm{Ga}^{3+}$, and $\mathrm{Si}^{4+}$ or by transition metals of groups II to VII, especially Ti and V [12]. Although, it is a complicated process, the insertion of transition elements by direct synthesis into Zeolite framework is advantageous, due to the possibility of achieving a high dispersion of the metal in the Zeolitic structure. Traditionally, the introduction of cationic ions or metal clusters in Zeolites extraframework positions is performed by cationic exchange [13, 14], impregnation [15], or chemical vapor deposition $[16,17]$ of metal precursors after Zeolite crystallization.

Since the first direct formation of synthesized Ti-Zeolite, TS-1, in 1983 [18], with a tetrahedral titanium atoms incorporated into the framework of MFI Zeolite structure, many kinds of Ti-containing molecular sieves such as Ti-Beta have been prepared because of their interesting catalytic properties [19-23]. Both Zeolites indicated the framework Ti atoms are in tetrahedral coordination. There are two main pathways for the formation of Ti-containing Zeolites: direct hydrothermal synthesis [24-27] and postsynthesis pathway [28-32]. Direct synthesis includes the presence of $\mathrm{Si}$ and $\mathrm{Ti}$ sources in the starting gel; meanwhile, the postsynthesis method comprises a vapor phase treatment of Zeolite with $\mathrm{TiCl}_{4}$ known as gassolid phase isomorphous substitution with $\mathrm{TiCl}_{4}$ or as CVD method [23, 29].

The synthetic difficulty of titanium incorporation into the Zeolite framework was the strong alkaline conditions for the synthesis of aluminosilicate Zeolites. Thus, most of the titanium-containing Zeolites reported so far, such as TS-1, TS-2, Ti- $\beta$, and Ti-MCM-41 [18, 33-35] have little aluminum in its framework. However, the synthesis of Ti-containing aluminosilicate Zeolite under strong alkaline conditions using titania-silica sol is also reported [36].

ZSM-5 was a matter of intensive investigation for the incorporation of titanium and it was found that titaniumcontaining $\mathrm{Y}$ Zeolites cannot be directly prepared by hydrothermal synthesis, but when the Zeolite [Li]Y was treated with $\mathrm{TiCI}_{4}$, [Li, Ti]Y was obtained with a titanium content of $12 \mathrm{~mol} \%$ [38] which is four times higher than that in [Ti]ZSM-5. XRD, ${ }^{29} \mathrm{Si}$ MAS NMR, and IR measurements indicated that dealumination of the framework occurs during tetanisation. Additional weak reflections in the XRD showed the presence of a small amount of Rutile but this does not account for all the titanium. Meanwhile, treating Alcontaining Zeolite (ZSM-5) with $\mathrm{TiCl}_{4}$ led to the synthesis of ZSM-11 structure, which is described as TS-2 wherein some of the aluminum of the ZSM-5 is substituted by titanium [39]. In the same context, Ti incorporated Y Zeolite was prepared by postsynthesis treatment of a dealuminated USY Zeolite with an aqueous solution of $\left(\mathrm{NH}_{4}\right)_{2} \mathrm{TiF}_{6}$ [40]. The results show that bulk $\mathrm{Si} / \mathrm{Al}$ ratio was considerably larger than that of the starting Zeolite, indicating the dealumination that occurred during tetanisation process. The XRD pattern of the titanated Zeolite showed no change other than slight decrease in the peak intensities. The obtained result also presented that the Ti species were tetrahedrally incorporated into the hydroxyl nests in the Zeolite framework under acidic conditions.

The difficulty of exchanging titanium cation with native cations in Zeolites arises from the fact that titanium cation precipitates under any conditions other than extremely acidic condition $(\mathrm{pH}>2)$, the same condition under which Zeolite structures are unstable and may suffer dealumination and even collapse [41]. Being the least stable Zeolite in acidic media, Ti-Zeolite Na-A is rarely reported in literature. The only recorded work was done by Kuznickl et al. [41], where a physical adsorption of $\mathrm{TiCl}_{3}$ is done by Zeolite-3A (KZeolite-A) pellets rather than by diffusion from the bulk solution.

As an inorganic material with aluminosilicate composition, Zeolites are known to possess biological activity. The incorporated water could be removed and substituted by different solutions; thus Zeolites can act as a delivery system, a process of which has already been exploited and applied in medicine [42]. Based on their unique characteristics, Zeolites are beneficial in medical and health care applications due to its biological activity, long term biological properties with chemical and biological stability [43], reversibly binding to small molecules as oxygen and nitric oxides [44, 45]. Furthermore, Zeolites well defined structures and catalytic effects make them an attractive model system for protein and enzyme mimetics [46]. They are also very effective as glucose adsorbent [47], antidiarrheal material [48], gastric antacid [49], and hypocholesterolemic [50]. Many accumulating evidences indicate their importance in regulating the immune system, as they act as nonspecific immunestimulators similarly to superantigens $[51,52]$.

As antitumor active materials, natural Zeolite, particularly clinoptilolite, is proved to possess a potential role as adjuvant chemotherapy applied after initial treatment for cancer, especially to suppress secondary tumor formation [53-55]. Its micronized form is found to interfere with the lipid peroxidation in the liver of cancer-bearing mice leading to a decrease in the tumor size, improvement of the overall health status, and prolonged life span. Specifically, the finely grinded clinoptilolite inhibits protein kinase B(c-Akt), induces the expression of $\mathrm{p} 21^{\mathrm{WAFI} / \mathrm{CIPI}}$ and $\mathrm{p} 27^{\mathrm{KIPI}}$ tumor 
suppressor protein, and blocks cell growth in several cancer cell lines [56].

Silver Zeolites are increasingly investigated as germicidal, bactericidal, antifungal, and antiseptic components in different compositions [57-59]. Zeolites Na-A has flavorless, odorless, and harmless properties. The ion-exchange process converts this low $\mathrm{Si} / \mathrm{Al}$ Zeolites into antimicrobial candidate when replacing its $\mathrm{Na}^{+}$ions with $\mathrm{Ag}^{+}, \mathrm{Cu}^{2+}$, and $\mathrm{Zn}^{2+}$ individually [60]. However, silver is the most common ion used in Zeolites-exchange process due to its stability and broad spectrum of antibacterial effects [61,62]. The use of silver ions and metallic silver as well as silver nanoparticles can be exploited in medicine for burn treatment, dental materials, coating stainless steel materials, textile fabrics, water treatment, sunscreen lotions, and so forth. They also possess low toxicity to human cells, high thermal stability, and low volatility [63].

In our previous study [64], we found that Ag-substituted Zeolites-A has an effective antitumor effects. The in vitro cytotoxic results of Z-Ag against lung carcinoma cell line (A549), human hepatocellular carcinoma cell line (HePG2), colon cell line carcinoma (HCT116), and human Caucasian breast adenocarcinoma (MCF7) were reported. The results were promising and revealed that the Ag-substituted micronized Zeolites-A can be used as novel antitumor drug.

There are many reports for different biomedical applications of natural and synthetic Zeolites found in some cation forms, generally silver and zinc [53,65-67]. No reports in the literature are recorded for antitumor activity of Ag-exchanged Ti-Zeolites Na-A.

In the present study, novel method foabr Ti-substituted Zeolites Na-A is formulated. The incorporation of Ti in the framework of Zeolites-A is achieved through a modified process of depositing thin coating layer of titanium by wet chemical method on a core of the starting Kaolin reactant in acidic conditions. Ti-coated Kaolin (Ti-K) is then thermally activated to prepare Ti-metakaolinite (Ti-MK) by calcination at high temperature before converting it into Ti-Zeolites (Ti$\mathrm{Z}$ ). The produced Ti-Zeolite is functionalized by silver (Ti-Z$\mathrm{Ag}$ ) and its cytotoxic activity is evaluated.

\section{Materials and Methods}

\subsection{Zeolites Preparation from Kaolin}

2.1.1. Coating of Kaolin by Titanium Tetrachloride. The Egyptian Kaolin used in this study has the following composition: $50.54 \mathrm{SiO}_{2}, 31.48 \mathrm{Al}_{2} \mathrm{O}_{3}, 1.87 \mathrm{Fe}_{2} \mathrm{O}_{3}$, and $2.26 \mathrm{TiO}_{2}$ (Wt.\%) and some other minor constituents containing $\mathrm{MgO}, \mathrm{CaO}$, $\mathrm{Na}_{2} \mathrm{O}$, and $\mathrm{SO}_{3}$. Sodium hydroxide pellets $(\mathrm{NaOH})$ is of analyzed ACS reagent with the composition of $98.6 \% \mathrm{NaOH}$ $+0.4 \%$ Chloride (Sigma-Aldrich). Kaolin with particle size range between 73 and $130 \mathrm{~nm}$ is coated by titanium using titanium tetrachloride following the method and scheme given by Ahmed and Selim, 2011 [37]

$$
\begin{aligned}
\mathrm{TiCl}_{4}+\text { Kaolin } \underset{\mathrm{NH}_{4} \mathrm{OH}}{\stackrel{\mathrm{HCl}}{\longrightarrow}} & \text { TiOH/Kaolin } \\
& +\mathrm{NH}_{4} \mathrm{Cl} \stackrel{500-750^{\circ} \mathrm{C}}{\longrightarrow} \mathrm{TiO}_{2} / \text { Kaolin }
\end{aligned}
$$

Based on the work of Ahmed and Selim, 2011 [37], coating of Kaolin particles by titanium proceeded by immersing certain amount of Kaolin in solutions containing different concentrations of titanium tetrachloride and hydrochloric acid, different periods of time to ensure good coverage. Ammonia solution is added dropwise to adjust the $\mathrm{pH}$. The produced Kaolin paste is then filtered through a Buchner system and washed before calcination at $700^{\circ} \mathrm{C}$ to obtain the thermally activated, Ti-metakaolinite (TMK). The concentration of $\mathrm{TiO}_{2}$ in the coating layer in the starting Kaolin reaches $1.26(\mathrm{Wt} \%)$ with a corresponding $0.76(\mathrm{Wt} \%)$ titanium.

2.1.2. Microwave Synthesis of Ti-Zeolites. Kaolin is commonly used as a starting material for synthesis of Zeolites-A since its $\mathrm{Si} / \mathrm{Al}$ ratio is near to unity as that of Zeolites-A $[68,69]$. Micronized Ti-Zeolites-A (Ti-Z-A), with an average grain size of less than $5 \mu \mathrm{m}$, is synthesized from the previously prepared Ti-coated metakaolinite (TMK) using microwave irradiation at low temperature of $80^{\circ} \mathrm{C}$ for $2 \mathrm{~h}$, following the method of Youssef et al., 2008 [70]. The concentration of $\mathrm{NaOH}$ used was $2 \mathrm{M}$ and the solid/liquid ratio of metakaolinite to alkaline solution was $1 \mathrm{~g} / 25 \mathrm{~mL}$. The microwave (MARS Extraction and Digestion system, Model XP-1500, CEM Corp., Matthews, NC) is used.

2.1.3. Preparation of Silver-Exchanged Zeolites. The obtained micronized Ti-containing Zeolites-A (Ti-Z-A) was modified to its Ag-exchanged form (Ti-Z-Ag) via immersing $5 \mathrm{~g}$ of Ti-Zeolites in $100 \mathrm{~cm}^{3}$ of $0.1 \mathrm{M}$ solution of extra pure silver nitrate (Scharlau chemicals, Spain) at $70^{\circ} \mathrm{C}$ for $6 \mathrm{~h}$ under magnetic stirring. The solid product was well washed with $250 \mathrm{~cm}^{3}$ deionized water and dried at $100^{\circ} \mathrm{C}$ for $24 \mathrm{~h} \mathrm{[71].}$

2.2. Characterization Techniques. In the present study, the chemical analysis of the starting Kaolin is obtained by X-ray fluorescence using XRF instrument model AXIOS, WD-XRF Sequential Spectrometer (Panalytical, 2005). Meanwhile, the determination of the mineralogical constituents of Egyptian Kaolin, metakaolinite, and Zeolites and its Ag-exchanged form was investigated by X-ray diffraction method, using BRUKUR $\mathrm{D}_{8}$ ADVANE with secondary monochromatic beam $\mathrm{Cu} K \alpha$ radiation at $\mathrm{Kv}=40$ and $\mathrm{mA}=40$. Functional groups of all materials were identified using Fourier transform infrared, FTIR, using MB154S, Bomem, Quebec, Canada equipment. Microstructures of the synthesized materials were scanned using TEM, SEM model Philips XL30 attached with EDX unit, using an accelerating voltage of $30 \mathrm{~K} . \mathrm{V}$., magnification $10 \mathrm{x}$ up to $400,000 \mathrm{x}$, and resolution for wavelength $(3.5 \mathrm{~nm})$, respectively. $\mathrm{AgNO}_{3}$ concentration of $0.1 \mathrm{M}$ exchanged onto the Zeolite was determined using atomic absorption spectra (Savant AA, GBC, Australia).

\subsection{Cytotoxic Activity of Ag-Exchanged Ti-Zeolites}

2.3.1. Method. The synthesized Ti-Zeolites are supplied to the Bioassay-Cell Culture Laboratory, National Research Centre, Cairo, Egypt, for in vitro antitumor screening on human hepatocellular carcinoma cell line (HePG2), colon cell line carcinoma (HCT116), lung carcinoma cell line (A549), and 
human Caucasian breast adenocarcinoma (MCF7) (American Type Culture Collection). Cell viability is assessed by the mitochondrial-dependent reduction of yellow MTT (3-(4,5dimethylthiazol-2-yl)-2,5-diphenyl tetrazolium bromide) to purple-blue insoluble formazan crystals [72].

2.3.2. Procedure. All the following procedures were done in a sterile area using a Laminar flow cabinet biosafety class II level (Baker, SG403INT, Sanford, ME, USA). Cells were cultured in RPMI 1640 medium for HePG2, HCT116, and MCF7, while being cultured in DMEM for A549. The media were supplemented with $1 \%$ antibiotic-antimycotic mixture $\left(10,000 \mathrm{U} / \mathrm{cm}^{3}\right.$ Potassium Penicillin, $10,000 \mu \mathrm{g} / \mathrm{cm}^{3}$ Streptomycin Sulfate, and $25 \mu \mathrm{g} / \mathrm{cm}^{3}$ Amphotericin B), 1\% Lglutamine, and $10 \%$ fetal bovine serum and kept at $37^{\circ} \mathrm{C}$ under $5 \% \mathrm{CO}_{2}$ and $95 \%$ humidity.

Cells were batch-cultured for 10 days and then seeded at concentration of $1 \times 10^{4}$ cells/well in fresh complete growth medium in 96 -well microtiter plastic plates at $37^{\circ} \mathrm{C}$ for $24 \mathrm{~h}$ under $5 \% \mathrm{CO}_{2}$ using a water jacketed carbon dioxide incubator (Sheldon, TC2323, Cornelius, OR, USA). Media were aspirated, fresh medium (without serum) was added, and cells were incubated either alone (negative control) or with different concentrations of sample to give a final concentration of $(100,50,25,12.5,6.25,3.125,1.56$, and $0.78 \mu \mathrm{g} / \mathrm{cm}^{3}$ ). $0.5 \%$ DMSO and $100 \mu \mathrm{g} / \mathrm{cm}^{3}$ of doxorubicin were used as negative and positive control, respectively. After $48 \mathrm{~h}$ of incubation, medium was aspirated, $40 \mathrm{~mm}^{3}$ MTT salt $\left(2.5 \mu \mathrm{g} / \mathrm{cm}^{3}\right)$ were added to each well and incubated for further four hours at $37^{\circ} \mathrm{C}$ under $5 \% \mathrm{CO}_{2}$. To stop the reaction and dissolving the formed crystals, a solution of $200 \mathrm{~mm}^{3}$ of $10 \%$ sodium dodecyl sulphate (SDS) in deionized water was added to each well and incubated overnight at $37^{\circ} \mathrm{C}$. A positive control, doxorubicin that is composed of $100 \mu \mathrm{g} / \mathrm{cm}^{3}$ was used as a known cytotoxic natural agent who gives 100\% lethality under the same conditions [73].

The absorbance was then measured using a microplate multiwell reader (Bio-Rad Laboratories Inc., model 3350, Hercules, California, USA) at $595 \mathrm{~nm}$ and a reference wavelength of $620 \mathrm{~nm}$. A statistical significance was tested between samples and negative control (cells with vehicle) using independent $t$-test by SPSS 11 program. DMSO is the vehicle used for dissolution of crystals of formazan and its final concentration on the cells was less than $0.2 \%$. The percent cytotoxicity was calculated according to the formula:

$$
\left[1-\left(\frac{\text { absorbance of treated cells }}{\text { absorbance of negative control }}\right)\right] \times 100 \text {. }
$$

A probit analysis was carried for $\mathrm{LC}_{50}$ determination using SPSS 11 program.

\section{Results and Discussion}

3.1. FTIR Result. The infrared spectrum of Kaolin coated with titanium tetrachloride is given in Figure 1. The midIR data show typical bands of Kaolin at 1112sh, 1091s, $1065 \mathrm{~s}$, and $1022 \mathrm{sm}^{-1}$ representing the $\mathrm{Si}-\mathrm{O}$ stretching

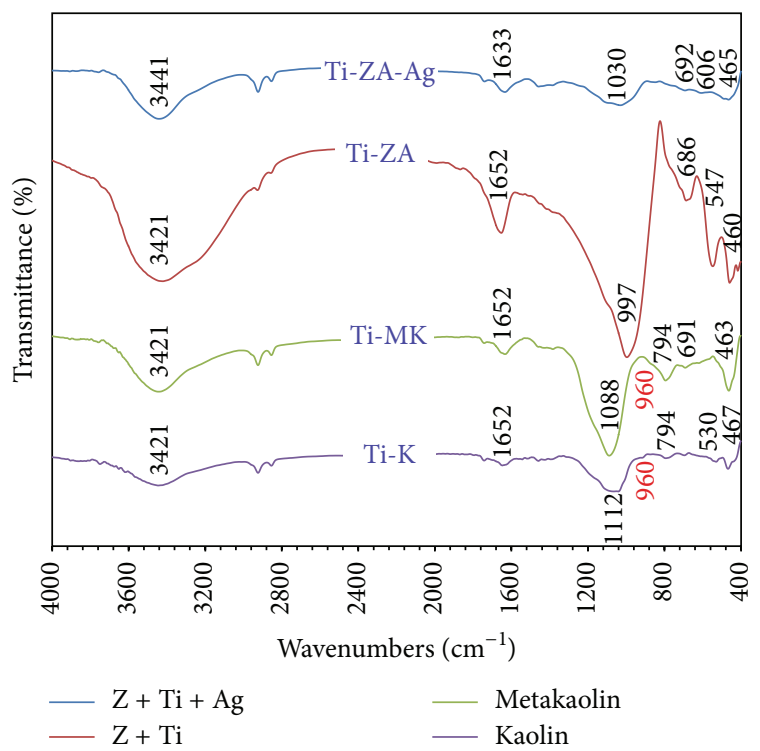

FIGURE 1: FTIR for the parent Kaolin before (Ti-K) and after (TiMK) calcination, Ti-Zeolite Na-A before (Ti-Z-A) and after silver substitution (Ti-Z-Ag).

vibrations, $794 \mathrm{w} \mathrm{cm}^{-1}$ assign to $v_{\mathrm{s}}(\mathrm{Si}-\mathrm{O}-\mathrm{Si}), 530 \mathrm{~m} \mathrm{~cm}^{-1}$ represents $\mathrm{Al}^{\mathrm{VI}}-\mathrm{O}$ stretching vibration and, finally, $467 \mathrm{~m}$ and $442 \mathrm{sh} \mathrm{cm}^{-1}$ peaks are corresponding to the deformation vibration of $\mathrm{Si}-\mathrm{O}$ [74].

Infrared bands $\left(\mathrm{cm}^{-1}\right)$ for Ti-K, Ti-MK, Ti-Zeolite Na-A, and Ti-Zeolite Ag-A are given in Table 1.

On calcination, metakaolinite is formed with intense bands at $1088 \mathrm{~s}$ and $794 \mathrm{~m} \mathrm{~cm}^{-1}$, as the major feature. For metakaolinite, the disappearance of the $530 \mathrm{~m} \mathrm{~cm}^{-1}$ band indicates the loss of $\mathrm{Al}[\mathrm{O}(\mathrm{OH})]_{6}[75]$. Bands which appear at $691 \mathrm{w}$ and $463 \mathrm{sh}$ may represent Anatase, which may have been formed during calcination.

Titanium-Zeolite prepared from titanium-metakaolinite is assigned by six main bands 997s \{asymmetric stretching vibrations of bridge bonds $v_{\text {as }} \mathrm{Si}-\mathrm{O}(\mathrm{Si})$ and $\left.\nu_{\text {as }} \mathrm{Si}-\mathrm{O}(\mathrm{Al})\right\}$, $686 \mathrm{~m}$ \{ Anatase and symmetric stretching vibrations of bridge bonds $\left.v_{\mathrm{s}} \mathrm{Si}-\mathrm{O}-\mathrm{Si}\right\}, 547 \mathrm{~m}$ \{complex band, symmetric stretching vibrations of bridge bonds $v_{s} \mathrm{Si}-\mathrm{O}-\mathrm{Si}$ and bending vibrations $\delta \mathrm{O}-\mathrm{Si}-\mathrm{O}\}, 460 \mathrm{~m}$ \{Anatase and bending vibrations $\delta$ O-Si-O occurring in antiphase $\}[76], 3421 \mathrm{vb}\{\mathrm{O}-$ $\mathrm{H}$ stretching\}, and $1652 \mathrm{~m}\left\{\mathrm{O}-\mathrm{H}\right.$ bending $\mathrm{cm}^{-1}$ associated with $-\mathrm{OH}$ absorption band, which is caused by physically adsorbed water or Zeolitic water\} [77].

The FTIR spectra of titanium-Zeolite-A structure when treated for Ag-substitution show shifts in positions of wavenumbers: $997 \mathrm{~s}$ to $1030 \mathrm{~b}, 686 \mathrm{~m}$ to $692 \mathrm{~m}, 547 \mathrm{~m}$ to $606 \mathrm{~m}$, and $460 \mathrm{~m}$ to $465 \mathrm{~m} \mathrm{~cm}^{-1}$, which improve the silver entry to the structural composition. Bands associated with water adsorbed by the Zeolite pores at $3421 \mathrm{vb}$ and $1652 \mathrm{~m} \mathrm{~cm}^{-1}$ slightly shifted to $3441 \mathrm{~s}$ and $1633 \mathrm{~m} \mathrm{~cm}^{-1}$ due to the presence of van der Waals interactions between the hydroxyl groups in the Zeolite structure related to $\mathrm{H}_{2} \mathrm{O}$ and the positive charge on the surface of $\mathrm{Ag}^{+}$[78]. The previous result improves the incorporation of silver ions into titanium-Zeolite structure. 
TAble 1: Infrared bands $\left(\mathrm{cm}^{-1}\right)$ for Ti-K, Ti-MK, Ti-Zeolite Na-A, and Ti-Zeolite Ag-A.

\begin{tabular}{lccc}
\hline Kaolin & Metakaolin coated with titanium & Zeolite incorporated with titanium & Zeolite incorporated with titanium and silver \\
\hline $1112 \mathrm{sh}, \mathrm{Si}-\mathrm{O}$ & $1088 \mathrm{~s}, \mathrm{Si}-\mathrm{O}$ & $997 \mathrm{~s}, \mathrm{Si}-\mathrm{O}(\mathrm{Si})$, and $\mathrm{Si}-\mathrm{O}(\mathrm{Al})$ & $1030 \mathrm{~b}, \mathrm{Si}-\mathrm{O}(\mathrm{Si})$, and $\mathrm{Si}-\mathrm{O}(\mathrm{Al})$ \\
$1091 \mathrm{~s}, \mathrm{Si}-\mathrm{O}$ & $794 \mathrm{~m}, \mathrm{Al}-\mathrm{O}$ & $686 \mathrm{~m}, \mathrm{Si}-\mathrm{O}-\mathrm{Si}$, and Anatase & $692 \mathrm{~m}, \mathrm{Si}-\mathrm{O}-\mathrm{Si}$, and Anatase \\
$1065 \mathrm{~s}, \mathrm{Si}-\mathrm{O}$ & $691 \mathrm{w}$, Anatase & $547 \mathrm{~m}, \mathrm{Si}-\mathrm{O}-\mathrm{Si}$, and O-Si-O & $606 \mathrm{~m}, \mathrm{Si}-\mathrm{O}-\mathrm{Si}$, and O-Si-O \\
$1022 \mathrm{~s}, \mathrm{Si}-\mathrm{O}$ & $463 \mathrm{sh}$, Anatase & $460 \mathrm{~m}, \mathrm{O}-\mathrm{Si}-\mathrm{O}$, and Anatase & $465 \mathrm{~m}, \mathrm{O}-\mathrm{Si}-\mathrm{O}$, and Anatase \\
$794 \mathrm{w}, \mathrm{Si}-\mathrm{O}-\mathrm{Si}$ & $794 \mathrm{sh}, \mathrm{Si}-\mathrm{O}-\mathrm{Si}$ & $3421 \mathrm{vb}, \mathrm{O}-\mathrm{H}$ & $3441 \mathrm{~s}, \mathrm{O}-\mathrm{H}$ \\
$530 \mathrm{~m}, \mathrm{Al}$ VI-O & $530 \mathrm{sh}, \mathrm{Al}^{\mathrm{VI}-\mathrm{O}}$ & $1652 \mathrm{~m}, \mathrm{O}-\mathrm{H}$ & $1633 \mathrm{~m}, \mathrm{O}-\mathrm{H}$ \\
$467 \mathrm{~m}, \mathrm{Si}-\mathrm{O}$ & & & \\
$442 \mathrm{sh}, \mathrm{Si}-\mathrm{O}$ & & & \\
\hline
\end{tabular}

The $960 \mathrm{~cm}^{-1}$ band is observed only in the IR-spectra of Al-containing Zeolites when the framework silica is substituted by titanium [79]. The previous band was firstly described as stretching vibration of a $\left(\mathrm{SiO}_{4}\right)$ unit bonded to titanium atom or as a vibrational band of the Ti-O-Si fragment $[80,81]$. However, after an extensive experimental IR and Raman studies, the band at about $960 \mathrm{~cm}^{-1}$ seemed to correspond to the stretching $\mathrm{Si}-\mathrm{O}$ vibrational mode perturbed by the presence of titanium $[79,82]$.

In the present work, a small shoulder appears at about $960 \mathrm{~cm}^{-1}$ in the Kaolinite and metakaolinite substituted with titanium (Figure 1). The very thin layer of titanium coating the Kaolin particle may account for the weak signal of such band.

3.2. X-Ray Fluorescence. Table 2 shows the X-ray fluorescence analysis of both the starting Kaolinite and its Ti-treated form after calcination. The XRF data show clear increase in the $\mathrm{Wt} \%$ of $\mathrm{TiO}_{2}$ from 2.26 in the parent Kaolinite to an amount of 7.18 in the coated metakaolinite, indicating the deposition of titanium on the precursor Kaolinite. In the same context, the ratio of $\mathrm{SiO}_{2} / \mathrm{TiO}_{2}$ suffers strong decrease from 22.36 in the uncoated to 7.42 in the coated samples. This probably suggests the incorporation of titanium in the Kaolinite structure.

We can also notice that the $\mathrm{Wt} \%$ ratio of $\mathrm{SiO}_{2} / \mathrm{Al}_{2} \mathrm{O}_{3}$ shows slight increase from 1.60 in Kaolinite to 1.63 in the $\mathrm{Ti}$ treated metakaolinite, which may account for the excess in quartz content of the treated calcined samples. Knowing that high acidic condition of the coating process turns Kaolinite less stable and titanium species highly reactive, this possibly facilitates the substitution of $\mathrm{Si}^{+4}$ by titanium cation in its position, with libration of an appreciable amount of silica which is then added to the quartz amount.

3.3. X-Ray Diffraction. Figure 2 represents the XRD pattern of calcined Ti-coated Kaolin when heated at $700^{\circ} \mathrm{C}$ to convert it to the activated metakaolinite (TMK), the amorphous precursor for Zeolite-Na-A. The obtained data shows very strong and sharp peaks of quartz (card\# 05-0490), cocrystallizes with very small amount of crystalline $\mathrm{TiO}_{2}$ phase, Anatase (card\# 71-1166). Anatase is a characteristic minor phase that normally developed as a secondary phase usually present in the parent kaolin. No other phases are present.
TABLE 2: Chemical analysis of the starting Kaolinite and Ti-treated form [37].

\begin{tabular}{lcc}
\hline Oxides & Kaolinite $\mathrm{Wt} \%$ & Ti-coated metakaolinite \\
\hline $\mathrm{SiO}_{2}$ & 50.54 & 53.33 \\
$\mathrm{Al}_{2} \mathrm{O}_{3}$ & 31.48 & 32.64 \\
$\mathrm{TiO}_{2}$ & 2.26 & 7.18 \\
$\mathrm{Fe}_{2} \mathrm{O}_{3}$ & 1.87 & 1.97 \\
$\mathrm{MgO}$ & 0.90 & 1.02 \\
$\mathrm{ZnO}$ & 0.01 & 0.06 \\
$\mathrm{CaO}$ & 0.66 & 0.85 \\
$\mathrm{Na}_{2} \mathrm{O}$ & 0.10 & 0.11 \\
$\mathrm{~K}_{2} \mathrm{O}$ & 0.07 & 0.07 \\
$\mathrm{P}_{2} \mathrm{O}_{5}$ & 0.08 & 0.09 \\
$\mathrm{SO}_{3}$ & 0.08 & 0.02 \\
$\mathrm{Cl}$ & 0.02 & 0.23 \\
L.O.I & 11.75 & 2.40 \\
Total & 100 & 100 \\
\hline
\end{tabular}

Figure 3 implies the XRD phases obtained in the synthetic product before (a) and after (b) Ag-substitution. Figure 3(a) represents the crystalline phases of Ti-Z-A, quartz, and Anatase which developed directly from the alkali attack of the Ti-metakaolinite at $80^{\circ} \mathrm{C}$ for $2 \mathrm{~h}$. XRD pattern of all phases shows strong and sharp peaks with high intensities, indicating well crystallinity. There is a complete matching in the peak positions for both diffractograms of Zeolite-Na-A and its Ag-substituted form, which indicates the stability of Zeolite structure.

The semiquantitative analysis of the peak intensities of the obtained product (Figure 3(a)) shows a corresponding crystalline percent of 35\% Zeolite-A (card\# 39-0222), 41\% quartz (card \#05-0490), and 4.4\% Anatase (card\# 71-1166). Meanwhile, the XRD profile of the Ag-substituted product (Figure 3(b)) shows the cocrystallization of 37\% ZeoliteA (card\# 39-0222), 2.7\% Ag-zeolite (card\# 83-2089), 20.1\% quartz (card \# 05-0490), and 3.1\% Anatase (card\# 71-1166). In addition, the XRD screened the presence of an unidentified Zeolitic phase in the synthetic product with a characteristic main peaks appeared at $d \AA$ values of $6.35,3.66$, and 2.58 with some other minor peaks.

The previous results indicate the formation of an excess amount of free quartz in the synthetic product, which is 


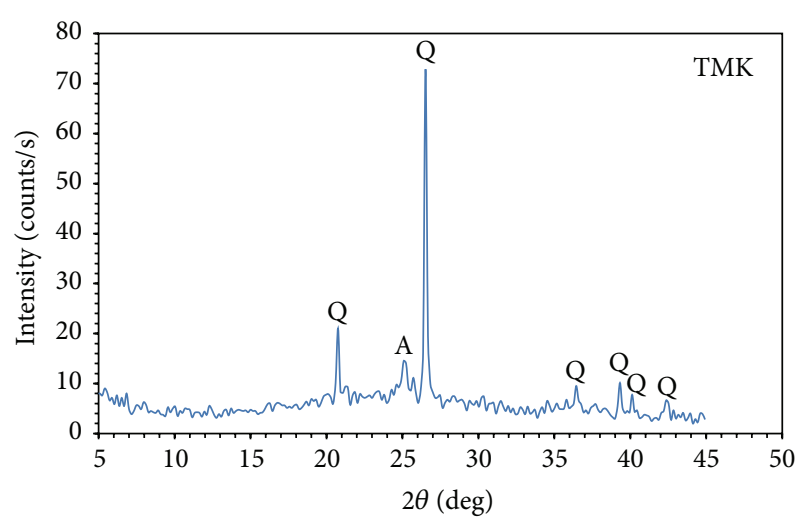

Q: quartz

A: Anatase

FIGURE 2: XRD pattern of the calcined Ti-containing Kaolin (Ti-metakaolinite) after calcination to metakaolinite (TMK) at $700^{\circ} \mathrm{C} / 4 \mathrm{~h}$.

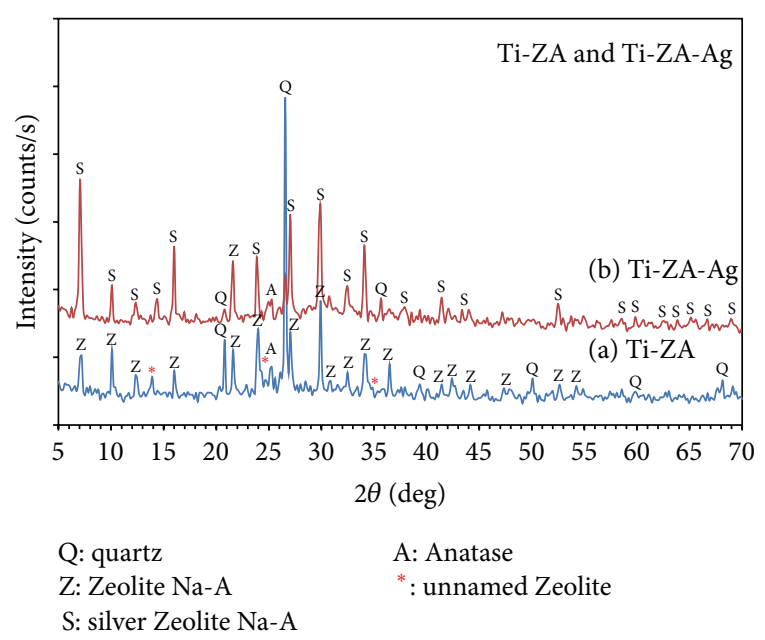

Figure 3: X-ray pattern for Ti-Zeolite (Ti-Z-A) and its silverexchanged form (Ti-Z-Ag).

much higher in its percent (44\%) than that recorded in the starting Kaolin (20\%). Furthermore, the crystallized Anatase $\left(\mathrm{TiO}_{2}\right)$ is within the normal percentage of that usually formed in Zeolites developed from Kaolins. This may indicate the substitution of tetrahedral $\mathrm{Si}$ by $\mathrm{Ti}$, a process that liberates silicon atoms responsible for the increase of quartz percentage.

The XRD data indicate the presence of $2.7 \%$ of Ag-zeolite in the Ag-substituted Ti-Z-A form, which supports the efficiency of the ion-exchanging process between $\mathrm{Na}^{+}$and $\mathrm{Ag}^{+}$.

The semiquantitative analysis of the phases implies drastic decrease in the free quartz content from $44 \%$ in the Ti-ZA (Figure 3(a)) to $20.1 \%$ in the Ti-Z-Ag sample (Figure 3(b)). The ion-exchanging process of $\mathrm{Na}^{+}$by $\mathrm{Ag}^{+}$releases sodium ions that may react with free quartz to form silicates [83], causing decrease in the free quartz content from $44 \%$ in $\mathrm{Ti}$ $\mathrm{Z}$-A to $20.1 \%$ in Ti-Z-Ag.

3.4. SEM and EDX. Figures 4(a), 4(b), and 4(c) represent the SEM micrographs for Ti-Zeolite Na-A (Ti-Z-A) and its
TABLE 3: EDX analysis for Ti-Zeolite (Ti-ZA).

\begin{tabular}{lcccc}
\hline \multirow{2}{*}{ Element } & \multicolumn{2}{c}{ Minute cubes } & \multicolumn{2}{c}{ Large cubes } \\
& Wt\% & At\% & Wt\% & At\% \\
\hline O K & 36.14 & 50.38 & 40.50 & 53.95 \\
$\mathrm{NaK}$ & 13.03 & 12.63 & 13.50 & 12.52 \\
$\mathrm{Al} \mathrm{K}$ & 17.29 & 14.29 & 17.82 & 13.65 \\
$\mathrm{Si} \mathrm{K}$ & 22.03 & 17.49 & 22.92 & 17.39 \\
$\mathrm{Ti}-\mathrm{K}$ & 9.23 & 4.30 & 4.55 & 2.02 \\
Fe K & 2.27 & 0.91 & 1.25 & 0.48 \\
\hline Total & 100.00 & 100 & 100 & 100 \\
\hline
\end{tabular}

TABLE 4: EDX percentage of atomic constituents (At\%) for starting precursor (Ti-MK), reference Zeolite, and Ti-Zeolite crystals of different generations.

\begin{tabular}{lcccc}
\hline \multirow{2}{*}{ At.\% ratio } & Ti-MK & \multirow{2}{*}{ Ref. Zeolite ${ }^{* *}$} & \multicolumn{2}{c}{ Ti-Zeolite } \\
Minute cube & Large cube \\
\hline $\mathrm{Si} / \mathrm{Al}$ & 1.28 & 1.03 & 1.29 & 1.27 \\
$\mathrm{Si} / \mathrm{Ti}$ & 5.72 & 17.11 & 4.07 & 8.61 \\
\hline
\end{tabular}

EDS average surface chemical analysis (average of more than 5 different crystals of the nearly the same size). The micrographs show well-developed crystalline mixture consists of characteristic cubic-shaped crystals of Zeolite-Na-A type with sharp edges and average grain size of less than $5.0 \mu \mathrm{m}$, copresent with large amount of minute rounded crystals of quartz. The microwave synthesis of oxides and powders usually yields products of relatively uniform crystals with narrow particle size distribution; however, in Figure 4(a), crystals seem related to different generations of development, having a wide range of grain size distribution expands from less than 0.25 to nearly about $5.0 \mu \mathrm{m}$. This may be explained by the presence of different sizes of the metakaolinite particles in the reaction medium with different thickness of titanium coverage. In the reaction medium, thick titanium masking (shell) of the small metakaolinite core, relative to thinner shell over larger ones, may lead to delayed reaction between the metakaolinite core and the alkali solution, resulting in different rates of crystallization and/or generations. Table 3 shows EDX analysis of "minute" and large cubes in Ti-Z-A.

Figures 4(b) and 4(c) and Tables 3 and 4 show the microanalysis for two extreme crystal generations: the early developed large crystals (Ec) and the lately formed minute crystals (Lc). Noticeably, both generations contain much higher $\mathrm{Si} / \mathrm{Al}$ ratios (1.29 and 1.27 for $\mathrm{Ec}$ and $\mathrm{Lc}$, resp.) than that recorded in the ideal Zeolite-Na-A type (1.03). Furthermore, the chemical composition of Zeolite product reveals clear reduction in their $\mathrm{Si} / \mathrm{Ti}$ ratio (4.07 for $\mathrm{Ec}$ and 8.61 for $\mathrm{Lc}$ ) from their reference Zeolite-Na-A (17.1), which means an increase in the Ti content of the formed Zeolite, especially for the very minute cubes. Minute cubes composition is regarded as good reflection of the chemical contents of Ti-metakaolinite 


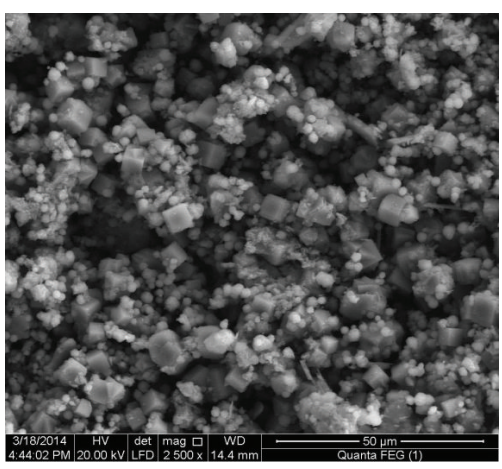

(a) Ti-Z-A

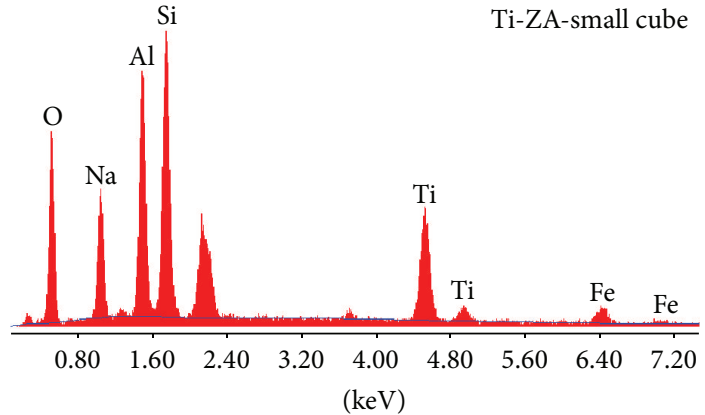

(b) Average composition for Lc

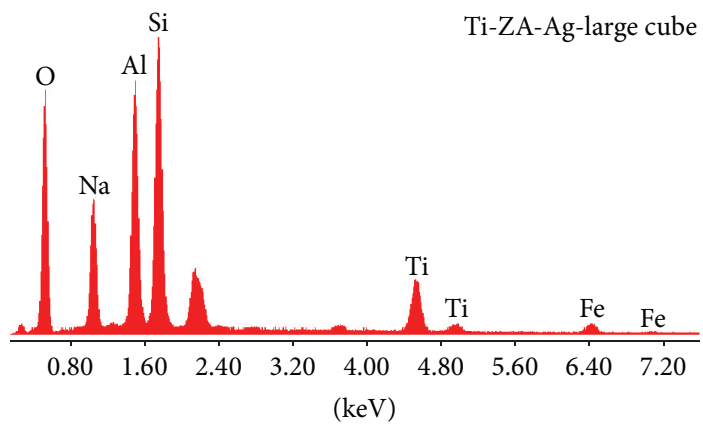

(c) Average composition for Ec

FIGURE 4: SEM micrographs for Ti-Z-A and its EDS analysis. Lc: late crystals = minute crystals. and Ec: early crystals = big crystals.

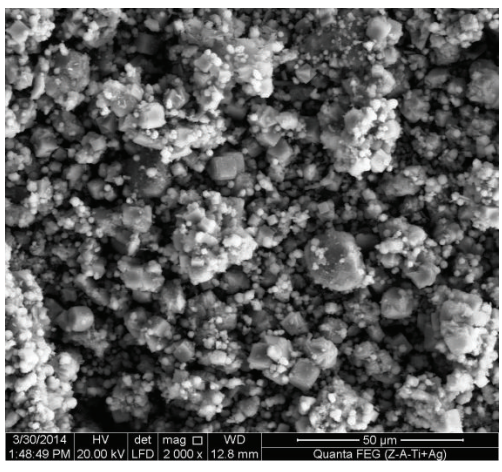

(a)

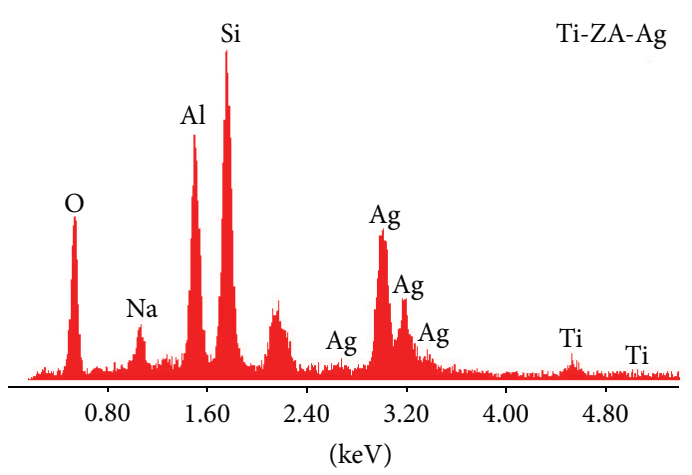

(b)

FIGURE 5: SEM and EDS chemical analysis for the Ag-substituted Ti-Z-A.

precursor, thus, supporting the idea of substitution of silicon by titanium.

The Ag-exchanged Zeolite implies brighter crystals than those seen in Figure 4(a). The brighter appearance might be due to the interaction between the microscope beams of electrons and the incorporated silver within Zeolite structure.

The SEM microstructure also shows that the Ti-Z-Ag crystals in Figure 5(a) show more rounded edges than Ti-Z-A crystals (Figure 4(a)).
Aluminosilicate Zeolite structures are unstable under acidic conditions and may suffer dealumination and even collapse [41]. This conclusion is supported by the XRD data, which showed reduction in the peak intensities of the crystalline Zeolite.

The Si/Al ratio also indicates an increase (1.42) than that recorded in the parent Kaolin and reference Zeolite, which again supports the idea of substituting $\mathrm{Si}$ by $\mathrm{Ti}$ in Zeolite structure. Titanium incorporated into the structure at 
TABLE 5: EDX microanalysis of the Ag-substituted Ti-Z-A.

\begin{tabular}{lcc}
\hline Element & Wt\% & At\% \\
\hline O K & 28.20 & 50.03 \\
NaK & 3.83 & 4.72 \\
$\mathrm{Al} \mathrm{K}$ & 14.07 & 14.81 \\
$\mathrm{Si} \mathrm{K}$ & 20.82 & 21.04 \\
$\mathrm{Ti}-\mathrm{K}$ & 2.08 & 1.23 \\
$\mathrm{Ag} \mathrm{K}$ & 31.01 & 8.16 \\
\hline Total & 100 & 100 \\
\hline
\end{tabular}

the expense of silicon which is given off as free quartz increasing the Silicon content.

In the current study, the $\mathrm{Wt} \%$ of silver (for initial $\mathrm{AgNO}_{3}$ concentrations of $0.1 \mathrm{M}$ ) exchanged onto the Zeolite determined by atomic absorption spectra (Savant AA, GBC, Australia) is $0.158 \%$ per Zeolite.

The EDS microanalysis of the Ti-Z-Ag given in Table 5 shows an obvious decrease in the At\% content of $\mathrm{Na}^{+}$from 13.5 in the Ti-Z-A into $4.72 \%$ in the Ag-exchanged form, indicating a partial substitution of $\mathrm{Na}^{+}$by $\mathrm{Ag}^{+}$. The noticeable increase of $\mathrm{Ag}^{+}$and detraction of $\mathrm{Na}^{+}$ions confirms the efficiency of the ion-exchanging process between $\mathrm{Na}^{+}$and $\mathrm{Ag}^{+}$, a result which the XRD result is confirming (Figure 3(b)).

In the present study, the concentration of the silver solution used in the exchanging process is in a diluted state of $0.1 \mathrm{M}$, which meets the minimum limit of $\mathrm{AgNO}_{3}$ concentration recommended for an efficient ion-exchange process [84]. The reason for maintaining the concentration of the silver solution at a diluted state is to prevent the oxidation of excess silver to silver oxide, which deposited in Zeolite pores that changes its effective porosity and surface area, affecting the availability of silver ions and reducing their activity.

3.5. In Vitro Cytotoxicity. In vitro cytotoxic activity evaluation of synthesized compounds (Ti-Z-Ag) was carried out against four human cancer cell lines including hepatocellular carcinoma (HePG2), colon carcinoma (HCT116), lung adenocarcinoma (A549), and breast adenocarcinoma (MCF7) using MTT method [72]. Doxorubicin $\mathrm{HCl}$, which is one of the most effective antitumor agents, is used as a reference drug (positive control) in this study. The relationship between drug concentrations and cell viability is plotted to calculate $\mathrm{LC}_{50}$ $\left(\mu \mathrm{g} / \mathrm{cm}^{3}\right)$ (lethal concentration of the sample that causes the death of $50 \%$ of cells in $48 \mathrm{~h}$ ), the value which corresponds to the concentration required for $50 \%$ inhibition of cell viability.

The screening summarized results in Table 6 and Figure 6 represent cytotoxic activity in terms of $\mathrm{LC}_{50}$ of Ti-Zeolite-A exchanged by Ag against the tested human cancer cell lines. Ti-Z-Ag causes death of $50 \%$ of tumor cells $\left(\mathrm{LC}_{50}\right)$ at concentrations of $15.1 \mu \mathrm{g} / \mathrm{cm}^{3}$ (37.8 for doxorubicin), $56.9 \mu \mathrm{g} / \mathrm{cm}^{3}$ (65.1 for doxorubicin), $39.1 \mu \mathrm{g} / \mathrm{cm}^{3}$ (48.8 for doxorubicin), and $18.8 \mu \mathrm{g} / \mathrm{cm}^{3}$ (45.02 for doxorubicin) against HePG2, HCT116, A549, and MCF7, respectively. Cytotoxic activity of Ti-Z-Ag is tested against normal human epithelial amnion cells and the $\mathrm{LC}_{50}$ was $49 \mu \mathrm{g} / \mathrm{cm}^{3}$, proving it is safe compound in comparison with doxorubicin.
TABLE 6: Cytotoxic screening of the novel synthesized Ti-Zeolite-A exchanged by Ag against the tested human cancer cell lines.

\begin{tabular}{lcc}
\hline Human cancer cell lines & $\begin{array}{c}\text { Ti-Zeolite-Ag } \\
\mathrm{LC}_{50}\left(\mu \mathrm{g} / \mathrm{cm}^{3}\right)\end{array}$ & $\begin{array}{c}{ }^{*} \text { Doxorubicin } \\
\mathrm{LC}_{50}\left(\mu \mathrm{g} / \mathrm{cm}^{3}\right)\end{array}$ \\
\hline HePG2 & 15.1 & 37.8 \\
HCT116 & 56.9 & 65.1 \\
A549 & 39.1 & 48.8 \\
MCF7 & 18.8 & 45.02 \\
\hline
\end{tabular}

${ }^{*}$ Positive control adriamycin (doxorubicin).

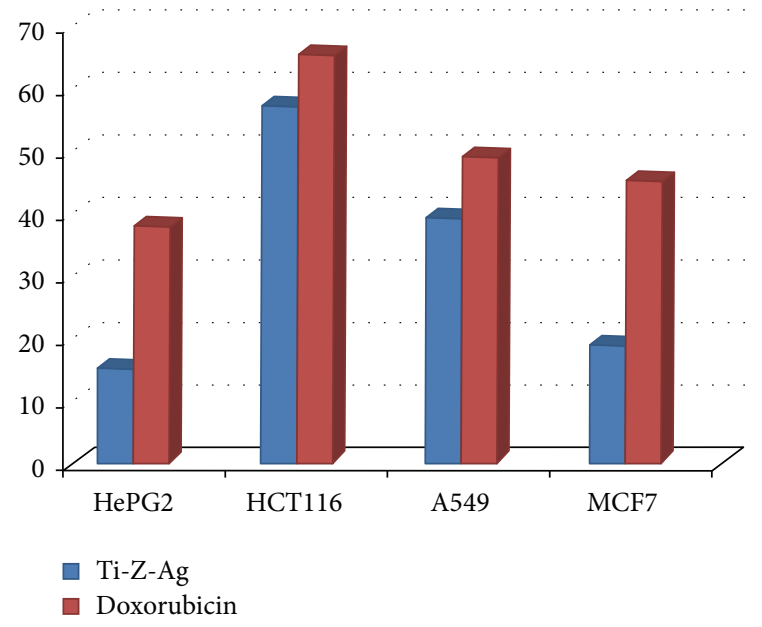

Figure 6: $\mathrm{LC}_{50} \mu \mathrm{M}$ of the prepared Ti-Z-Ag against carcinoma cell line compared with doxorubicin (positive control).

The results revealed that cytotoxic activity of Ti-Z-Ag against HePG2, HCT116, A549, and MCF7 is astonishing and this safe compound can be considered after stages of clinical testing as a new antitumor drug.

Ag-NPs have the ability to inhibit angiogenesis, the pivotal step in tumor growth [85]. Compounds possessing antiangiogenic properties are known for their potential ability to block the activity of abnormally expressed signaling proteins, such as Ras and Akt, cytokine-based therapies, DNA- or protein-based vaccines against specific tumor markers, and tyrosine kinase inhibitors which exhibit a consistent antitumor effect [86].

The cytotoxic effects of silver are the result of active physical-chemical interaction of silver atoms with the functional groups of intracellular proteins, as well as with the nitrogen bases and phosphate groups in DNA [87]. It was also further implied that silver particles are directly toxic to the cancer cells through Caspase 3 activation [88], DNA fragmentation [89], and/or increased production of reactive oxygen species [90].

The actual pathways by which silver inhibits the pathway mediating cell proliferation and viability are yet to be explored.

\section{Conclusion}

In conclusion, novel method for the direct incorporation of $\mathrm{Ti}$ atoms into the structure of Kaolinite, the precursor of 
Zeolite-Na-A, is investigated in this study. The direct substitution of Si by $\mathrm{Ti}$ atoms in the tetrahedral position occurs. The scheme and mechanism are as follows.

The Kaolin sheets ( $\mathrm{Si}$ and $\mathrm{Al}$ ) are coated by Ti shell using titanium tetrachloride in a core-shell application process under acidic media. Under such acidic conditions, titanium cation is highly active, whereas Kaolinite structure is unstable. Thus, a proposed substitution of tetrahedral silicon by titanium can occur, resulting in Ti-Kaolinite. The calcination at high temperature of $700^{\circ} \mathrm{C}$ converts the Ti-Kaolinite to amorphous Ti-metakaolinite, the precursor of Ti-Zeolite $\mathrm{Na}-\mathrm{A}$. Finally, the alkali treatment of the Ti-precursor at $80^{\circ} \mathrm{C} / 2 \mathrm{~h}$ under microwave hydrothermal conditions leads to Ti-Zeolite Na-A. Functionalization of Ti-Zeolite by silver results in Ag-Zeolite form. The cytotoxic activity of the Ag form of Ti-Zeolite $\mathrm{Na}-\mathrm{A}$ is evaluated.

The evidences of Ti-Zeolite Na-A synthesis are summarized in the following points.

(1) All testing tools, XRD, XRF, EDX, and IR measurements, indicate clear increase in the silicon content led to increase of $\mathrm{Si} / \mathrm{Al}$ ratios in Ti-Kaolinite, metakaolinite, and prepared Zeolite. Desilication of the framework is proved to occur during tetanisation process of different Zeolite structures [40-43].

(2) XRD for Kaolin, metakaolinite, and Zeolite witnessed clear increase in the free silica which accounts for the noticeable increase in the quartz content.

(3) The increase of quartz content is an evidence of silica libration due its substitution by titanium.

(4) In the coating process, the prevailing acidic conditions are turning $\mathrm{Ti}$ ions very active to replace the $\mathrm{Si}$, resulting in the liberation of the substituted silica to be added to the free silica already present in the Kaolin. Thus, the XRD and EDX indicate stronger peaks of quartz as well as higher $\mathrm{Si} / \mathrm{Al}$ ratio in the prepared $\mathrm{Ti}$ Zeolite than unity.

(5) The constant percent of Anatase $\left(\mathrm{TiO}_{2}\right)$ phase in both the metakaolin and prepared Zeolite indicates a probable incorporation of $\mathrm{Ti}$ in the framework of Zeolite-A.

(6) The obtained $\mathrm{Si} / \mathrm{Al}$ and $\mathrm{Si} / \mathrm{Ti}$ ratios for different generations of Zeolite crystals are higher than that of their parent Kaolin, supporting the idea of substituting $\mathrm{Si}$ by $\mathrm{Ti}$. The concentration of silicon as free quartz increases as being replaced by titanium.

When compared with doxorubicin, in vitro cytotoxic result of Ag-substituted micronized Ti-Zeolite-A shows the highest efficiency against human hepatocellular carcinoma cell line (HePG2) followed by human Caucasian breast adenocarcinoma (MCF7) then lung carcinoma cell line (A549) and finally against colon cell line carcinoma (HCT116). TiZeolite-A is a safe compound and can be considered a new antitumor drug.

\section{Conflict of Interests}

The authors declare that there is no conflict of interests regarding the publication of this paper.

\section{Acknowledgments}

The authors wish to thank Professor Nivin Ahmed for her help. They are also grateful to the National Research Centre and Faculty of Science, Suez University, for supporting this work.

\section{References}

[1] C. S. Cundy and P. A. Cox, "The hydrothermal synthesis of zeolites: history and development from the earliest days to the present time," Chemical Reviews, vol. 103, no. 3, pp. 663-701, 2003.

[2] W. M. Meier, D. H. Olson, and C. Baerlocher, Atlas of Zeolite Structure Types, International Zeolite Association, Elsevier, London, UK, 1996.

[3] D. Breck, Zeolite Molecular Sieves: Structure, Chemistry, and Use, Wiley, New York, NY, USA, 1974.

[4] M. Sathupunya, E. Gulari, A. Jamieson, and S. Wongkasemjit, "Microwave-assisted preparation of zeolite K-H from alumatrane and silatrane," Microporous and Mesoporous Materials, vol. 69, no. 3, pp. 157-164, 2004.

[5] M. Sathupunya, E. Gulari, and S. Wongkasemjit, "Na-A (LTA) zeolite synthesis directly from alumatrane and silatrane by solgel microwave techniques," Journal of the European Ceramic Society, vol. 23, no. 8, pp. 1293-1303, 2003.

[6] P. Phiriyawirut, R. Magaraphan, A. M. Jamieson, and S. Wongkasemjit, "Morphology study of MFI zeolite synthesized directly from silatrane and alumatrane via the sol-gel process and microwave heating," Microporous and Mesoporous Materials, vol. 64, no. 1-3, pp. 83-93, 2003.

[7] K. Kunii, K. Narahara, and S. Yamanaka, "Template-free synthesis of $\mathrm{AlPO}_{4}-\mathrm{H} 1,-\mathrm{H} 2$, and $-\mathrm{H} 3$ by microwave heating," Microporous and Mesoporous Materials, vol. 52, no. 3, pp. 159$167,2002$.

[8] S. Komarneni and A. S. Bhalla, "Mechanism of microwave heating of zeolite A," Journal of Porous Materials, vol. 8, no. 1, pp. 23-35, 2001.

[9] R. Szostak, Handbook of Molecular Sieves, van Nostrand Reinhold, New York, NY, USA, 1992.

[10] J. C. M. Muller, G. Hakvoort, and J. C. Jansen, "DSC and TG study of water adsorption and desorption on zeolite NaA: powder and attached as layer on metal," Journal of Thermal Analysis and Calorimetry, vol. 53, no. 2, pp. 449-466, 1998.

[11] H. van Bekkum, J. C. Jansen, and E. M. Flanigen, "Zeolites and molecular sieves," in Introduction to Zeolite Science and Practice, H. van Bekkum, J. C. Jansen, and E. M. Flanigen, Eds., pp. 13-33, Elsevier, Amsterdam, The Netherlands, 1991.

[12] J. C. van der Waal, M. S. Rigutto, and H. van Bekkum, "Zeolite titanium beta as a selective catalyst in the epoxidation of bulky alkenes," Applied Catalysis A: General, vol. 167, no. 2, pp. 331342, 1998.

[13] L. Guczi and I. Kiricsi, "Zeolite supported mono- and bimetallic systems: structure and performance as $\mathrm{CO}$ hydrogenation catalysts," Applied Catalysis A: General, vol. 186, no. 1-2, pp. 375394, 1999. 
[14] X. Li and E. Iglesia, "Pt/[Fe]ZSM-5 modified by Na and Cs cations: an active and selective catalyst for dehydrogenation of $n$-alkanes to $n$-alkenes," Chemical Communications, vol. 8 , no. 5, pp. 594-596, 2008.

[15] J. Guzman and B. C. Gates, "Supported molecular catalysts: metal complexes and clusters on oxides and zeolites," Journal of the Chemical Society, Dalton Transactions, no. 17, pp. 3303-3318, 2003.

[16] Y. Okamoto, Y. Inui, H. Onimatsu, and T. Imanaka, "Identification, thermal stability, and catalytic property of tetracarbonylchromium(0) encapsulated in NaX zeolite," Journal of Physical Chemistry, vol. 95, no. 12, pp. 4596-4598, 1991.

[17] S. Recchia, C. Dossi, A. Fusi, L. Sordelli, and R. Psaro, "Zeolite-supported metals by design: organometallic-based tinpromoted rhodium/NaY catalysts," Applied Catalysis A, vol. 182, no. 1, pp. 41-51, 1999.

[18] M. Taramasso, S. D. Millanese, G. M. Perego, and B. Notari, "Preparation of porous crystalline synthetic material comprised of silicon and titanium oxides," U.S. Patent 4410501, 1983.

[19] A. Thangaraj, R. Kumar, and P. Ratnasamy, "Direct catalytic hydroxylation of benzene with hydrogen peroxide over titanium-silicate zeolites," Applied Catalysis, vol. 57, no. 1, pp. L1L3, 1990.

[20] M. G. Clerici and U. Romana, "A process for the epoxydation of olefinic compounds," Europrean Patent no. 0,230,949, A2, 1987.

[21] A. Thangaraj, S. Sivasanker, and P. Ratnasamy, "Catalytic properties of titanium silicalites. IV. Vapour phase beckmann rearrangement of cyclohexanone oxime," Journal of Catalysis, vol. 137, no. 1, pp. 252-256, 1992.

[22] D. R. C. Huybrechts, L. de Bruycker, and P. A. Jacobs, "Oxyfunctionalization of alkanes with hydrogen peroxide on titanium silicalite," Nature, vol. 345, no. 6272, pp. 240-242, 1990.

[23] B. Kraushaar and J. H. C. van Hooff, "A new method for the preparation of titanium-silicalite (TS-1)," Catalysis Letters, vol. 1, no. 4, pp. 81-84, 1988.

[24] C. Perego, A. Carati, P. Ingallina, M. A. Mantegazza, and G. Bellussi, "Production of titanium containing molecular sieves and their application in catalysis," Applied Catalysis A, vol. 221, no. 1-2, pp. 63-72, 2001.

[25] T. Blasco, M. A. Camblor, A. Corma et al., "Unseeded synthesis of Al-free $\mathrm{Ti}-\beta$ zeolite in fluoride medium: a hydrophobic selective oxidation catalyst," Chemical Communications, no. 20, pp. 2367-2368, 1996.

[26] M. J. Díaz-Cabañas, L. A. Villaescusa, and M. A. Camblor, "Synthesis and catalytic activity of Ti-ITQ-7: a new oxidation catalyst with a three-dimensional system of large pore channels," Chemical Communications, vol. 9, pp. 761-762, 2000.

[27] M. Moliner, P. Serna, A. Cantín, G. Sastre, M. J. Díaz-Cabañas, and A. Corma, "Synthesis of the Ti-silicate form of BEC polymorph of $\beta$-zeolite assisted by molecular modeling," The Journal of Physical Chemistry C, vol. 112, no. 49, pp. 19547-19554, 2008.

[28] S. Krijnen, P. Sánchez, B. T. F. Jakobs, and J. H. C. Van Hooff, "A controlled post-synthesis route to well-defined and active titanium Beta epoxidation catalysts," Microporous and Mesoporous Materials, vol. 31, no. 1-2, pp. 163-173, 1999.

[29] J. W. Yoo, C. W. Lee, J.-S. Chang, S.-E. Park, and J. Ko, "Characterization and catalytic properties of Ti-ZSM-5 prepared by chemical vapor deposition," Catalysis Letters, vol. 66, no. 3, pp. 169-173, 2000.
[30] C.-H. Xu, T. Jin, S. H. Jhung et al., "Incorporation of titanium into H-ZSM-5 zeolite via chemical vapor deposition: effect of steam treatment," Bulletin of the Korean Chemical Society, vol. 25, no. 5, pp. 681-686, 2004.

[31] P. Wu, T. Tatsumi, T. Komatsu, and T. Yashima, "Hydrothermal synthesis of a novel titanosilicate with MWW topology," Chemistry Letters, no. 7, pp. 774-775, 2000.

[32] W. Fan, P. Wu, S. Namba, and T. Tatsumi, "A titanosilicate that is structurally analogous to an MWW-type lamellar precursor," Angewandte Chemie, vol. 43, no. 2, pp. 236-240, 2003.

[33] J. Sudhakar Reddy and R. Kumar, "Crystallization kinetics of a new titanium silicate with MEL structure (TS-2)," Zeolites, vol. 12, no. 1, pp. 95-100, 1992.

[34] T. Blasco, M. A. Camblor, A. Corma, and J. Pérez-Pariente, “The state of $\mathrm{Ti}$ in titanoaluminosilicates isomorphous with zeolite $\beta$," Journal of the American Chemical Society, vol. 115, no. 25, pp. 11806-11813, 1993.

[35] A. Corma, M. T. Navarro, and J. P. Pariente, "Synthesis of an ultralarge pore titanium silicate isomorphous to MCM41 and its application as a catalyst for selective oxidation of hydrocarbons," Journal of the Chemical Society, Chemical Communications, no. 2, pp. 147-148, 1994.

[36] J. H. Kwak, S. J. Cho, and R. Ryoo, "A new synthesis procedure for titanium-containing zeolites under strong alkaline conditions and the catalytic activity for partial oxidation and photocatalytic decomposition," Catalysis Letters, vol. 37, pp. 217221, 1996.

[37] N. M. Ahmed and M. Selim, "Innovative titanium dioxidekaolin mixed pigments performance in anticorrosive paints," Pigment \& Resin Technology, vol. 40, no. 1, pp. 4-16, 2011.

[38] E. Schultz, C. Ferrini, and R. Prins, "X-ray absorption investigations on Ti-containing zeolites," Catalysis Letters, vol. 14, no. 2, pp. 221-231, 1992.

[39] J. S. Reddy, R. Kumar, and P. Ratnasamy, "Titanium silicalite2: synthesis, characterization and catalytic properties," Applied Catalysis, vol. 58, no. 1, pp. L1-L4, 1990.

[40] Y. Oumi, T. Manabe, H. Sasaki, T. Inuzuka, and T. Sano, "Preparation of Ti incorporated y zeolites by a post-synthesis method under acidic conditions and their catalytic properties," Applied Catalysis A: General, vol. 388, no. 1-2, pp. 256-261, 2010.

[41] S. M. Kuznickl, K. L. DeVries, and E. M. Eyring, "An ESR study of titanium(III)-exchanged zeolite A," The Journal of Physical Chemistry, vol. 84, no. 5, pp. 535-537, 1980.

[42] K. Pavelić and M. Hadzija, "Medical application of zeolites," in Handbook of Zeolite Science and Technology, S. M. Auerbach, K. A. Carrado, and P. K. Dutta, Eds., chapter 24, CRC Press, 2003.

[43] Z. Li, S. J. Roy, Y. Zou, and R. S. Bowman, "Long-term chemical and biological stability of surfactant-modified zeolite," Environmental Science and Technology, vol. 32, no. 17, pp. 26282632, 1998 .

[44] H. Liu, H. M. Kao, and C. P. Grey, in Proceedings of the 12th International Zeolite Conference, M. J. M. Tracy, B. K. Marcus, Me. Bisher, and J. R. Higgins, Eds., pp. 2317-2340, Material Research Society, Warrendale, Pa, USA, 1999.

[45] A. Seidel, A. Gutsze, and B. Boddenberg, "Lewis acid sites in zeolite Y studied by adsorption, EPR, and NMR techniques," in Proceedings of the 12th International Zeolite Conference, M. J. M. Tracy, B. K. Marcus, Me. Bisher, and J. R. Higgins, Eds., pp. 2589-2618, Material Research Society, Warrendale, Pa, USA, 1999. 
[46] F. Bedioui, "Zeolite-encapsulated and clay-intercalated metal porphyrin, phthalocyanine and schiff-base complexes as models for biomimetic oxidation catalysts-an overview," Coordination Chemistry Reviews, vol. 144, pp. 39-68, 1995.

[47] B. Concepción-Rosabal, G. Rodriguez-Fuentes, and R. SimónCarballo, "Development and featuring of the zeolitic active principle FZ: a glucose adsorbent," Zeolites, vol. 19, no. 1, pp. 4750, 1997.

[48] G. Rodríguez-Fuentes, M. A. Barrios, A. Iraizoz, I. Perdomo, and B. Cedré, "Enterex: anti-diarrheic drug based on purified natural clinoptilolite," Zeolites, vol. 19, no. 5-6, pp. 441-448, 1997.

[49] G. Rodríguez-Fuentes, A. R. Denis, M. A. B. Álvarez, and A. I. Colarte, "Antacid drug based on purified natural clinoptilolite," Microporous and Mesoporous Materials, vol. 94, no. 1-3, pp. 200-207, 2006.

[50] R. Simon-Carballo, A. Fleitas, J. Alvarez, and G. RodriguezFuentes, "Hypocholesterolemic action of cholestine in cholesterol fed animals," in Zeolite'97: Occurrence, Properties, and Utilization of Natural Zeolites (Program and Abstracts), pp. 106108, De Frede, Naples, Italy, 1997.

[51] A. Ueki, M. Yamaguchi, H. Ueki et al., "Polyclonal human Tcell activation by silicate in vitro," Immunology, vol. 82, no. 2, pp. 332-335, 1994.

[52] T. Aikoh, A. Tomokuni, T. Matsukii et al., "Activation-induced cell death in human peripheral blood lymphocytes after stimulation with silicate in vitro," International Journal of Oncology, vol. 12, no. 6, pp. 1355-1359, 1998.

[53] K. Pavelić, M. Hadžija, L. Bedrica et al., "Natural zeolite clinoptilolite: new adjuvant in anticancer therapy," Journal of Molecular Medicine, vol. 78, no. 12, pp. 708-720, 2001.

[54] K. Pavelic, M. Katic, V. Sverko et al., "Immunostimulatory effect of natural clinoptilolite as a possible mechanism of its antimetastatic ability," Journal of Cancer Research and Clinical Oncology, vol. 128, no. 1, pp. 37-44, 2002.

[55] M. Poljak-Blazi, M. Katic, M. Kralj et al., "In vitro and in vivo effect of natural clinoptilolite on malignant tumors," Studies in Surface Science and Catalysis, vol. 135, pp. 5309-5316, 2001.

[56] N. Zarkovic, K. Zarkovic, M. Kralj et al., "Anticancer and antioxidative effects of micronized zeolite clinoptilolite," Anticancer Research, vol. 23, no. 2B, pp. 1589-1595, 2003.

[57] Z. Hagiwara, S. Hoshiro, S. Nohara, and K. Tagawa, "Zeolite Particles Retaining Silver Ions having Antibacterial Properties," U.S. Patent 4,911,898, 1990.

[58] K. Kawahara, K. Tsuruda, M. Morishita, and M. Uchida, "Antibacterial effect of silver-zeolite on oral bacteria under anaerobic conditions," Dental Materials, vol. 16, no. 6, pp. 452$455,2000$.

[59] H. J. Klasen, "A historical review of the use of silver in the treatment of burns. II. Renewed interest for silver," Burns, vol. 26, no. 2, pp. 131-138, 2000.

[60] S. Demirci, Z. Ustaoğlu, G. A. Yılmazer, F. Sahin, and N. Baç, "Antimicrobial properties of Zeolite-X and Zeolite-A ionexchanged with silver, copper, and zinc against a broad range of microorganisms," Applied Biochemistry and Biotechnology, vol. 172, no. 3, pp. 1652-1662, 2014.

[61] K. Shameli, M. B. Ahmad, W. M. Z. W. Yunus et al., "Green synthesis of silver/montmorillonite/chitosan bionanocomposites using the UV irradiation method and evaluation of antibacterial activity," International Journal of Nanomedicine, vol. 5, no. 1, pp. 875-887, 2010.
[62] M. B. Ahmad, K. Shameli, W. M. Z. W. Yunus et al., "Synthesis and antibacterial activity of silver/montmorillonite nanocomposites," Research Journal of Biological Sciences, vol. 4, no. 9, pp. 1032-1036, 2009.

[63] N. Duran, P. D. Marcarto, G. I. H. De Souza, O. L. Alves, and E. Esposito, "Antibacterial effect of silver nanoparticles produced by fungal process on textile fabrics and their effluent treatment," Journal of Biomedical Nanotechnology, vol. 3, pp. 203-208, 2007.

[64] H. F. Youssef and W. H. Hegazy, "Microwave preparation and characterization of Ag-substituted micronized Zeolite-A from purified Egyptian kaolin and evaluation of its antitumor activity," Microporous and Mesoporous Materials. In press.

[65] Y. Abe, M. Ueshige, M. Takeuchi, M. Ishii, and Y. Akagawa, "Cytotoxicity of antimicrobial tissue conditioners containing silver-zeolite," International Journal of Prosthodontics, vol. 16, no. 2, pp. 141-144, 2003.

[66] M. M. Cowan, K. Z. Abshire, S. L. Houk, and S. M. Evans, "Antimicrobial efficacy of a silver-zeolite matrix coating on stainless steel," Journal of Industrial Microbiology and Biotechnology, vol. 30, no. 2, pp. 102-106, 2003.

[67] M. Hotta, H. Nakajima, K. Yamamoto, and M. Aono, "Antibacterial temporary filling materials: the effect of adding various ratios of Ag-Zn-Zeolite," Journal of Oral Rehabilitation, vol. 25, no. 7, pp. 485-489, 1998.

[68] S. Chandrasekhar and P. N. Pramada, "Sintering behaviour of calcium exchanged low silica zeolites synthesized from kaolin," Ceramics International, vol. 27, no. 1, pp. 105-114, 2001.

[69] J. Rosha and J. Klinowski, "Solid-state NMR studies of the structure and reactivity of metakaolinite," Angewandte Chemie, vol. 29, no. 5, pp. 553-554, 1990.

[70] H. F. Youssef, D. M. Ibrahim, and S. Komarneni, "Microwaveassisted versus conventional synthesis of zeolite A from metakaolinite," Microporous and Mesoporous Materials, vol. 115, no. 3, pp. 527-534, 2008.

[71] M. J. Sánchez, P. Gamero, and D. Cortés, "Bioactivity assessment of ZSM-5 type zeolite functionalized with silver or zinc," Materials Letters, vol. 74, pp. 250-253, 2012.

[72] T. Mosmann, "Rapid colorimetric assay for cellular growth and survival: application to proliferation and cytotoxicity assays," Journal of Immunological Methods, vol. 65, no. 1-2, pp. 55-63, 1983.

[73] M. I. Thabrew, R. D. Hughes, and I. G. McFarlane, "Screening of hepatoprotective plant components using a HepG2 cell cytotoxicity assay," Journal of Pharmacy and Pharmacology, vol. 49, no. 11, pp. 1132-1135, 1997.

[74] M. Alkan, C. Hopa, Z. Yilmaz, and H. Guler, "The effect of alkali concentration and solid/liquid ratio on the hydrothermal synthesis of zeolite NaA from natural kaolinite," Microporous and Mesoporous Materials, vol. 86, no. 1-3, pp. 176-184, 2005.

[75] S. Chandrasekhar, "Influence of metakaolinization temperature on the formation of zeolite 4A from kaolin," Clay Minerals, vol. 31, no. 2, pp. 253-261, 1996.

[76] W. Mozgawa, M. Król, and K. Barczyk, "FT-IR studies of zeolites from different structural groups," Chemik, vol. 65, no. 7, pp. 667674, 2011.

[77] F. Shi, L. Wang, and J. Liu, "Synthesis and characterization of silica aerogels by a novel fast ambient pressure drying process," Materials Letters, vol. 60, no. 29-30, pp. 3718-3722, 2006.

[78] K. Shameli, M. B. Ahmad, W. Z. W. Yunus, N. A. Ibrahim, and M. Darroudi, "Synthesis and characterization of silver/talc nanocomposites using the wet chemical reduction method," 
International Journal of Nanomedicine, vol. 5, no. 1, pp. 743-751, 2010.

[79] G. N. Vayssilov, "Structural and physicochemical features of titanium silicalites," Catalysis Reviews: Science and Engineering, vol. 39, no. 3, pp. 209-251, 1997.

[80] A. Carati, C. Flego, E. Previde Massara et al., "Stability of Ti in MFI and Beta structures: a comparative study," Microporous and Mesoporous Materials, vol. 30, no. 1, pp. 137-144, 1999.

[81] M. R. Boccuti, K. M. Rao, A. Zecchina, G. Leofanti, and G. Petrini, "Spectroscopic characterization of silicalite and titanium-silicalite," Studies in Surface Science and Catalysis, vol. 48, pp. 133-144, 1989.

[82] G. Bellussi, A. Carati, M. G. Clerici, G. Maddinelli, and R. Millini, "Reactions of titanium silicalite with protic molecules and hydrogen peroxide," Journal of Catalysis, vol. 133, no. 1, pp. 220-230, 1992.

[83] N. N. Greenwood and A. Earnshaw, Chemistry of the Elements, Pergamon Press, Oxford, UK, 1984.

[84] Z. Hagiwara, S. Hoshiuo, H. Ishino, S. Nohara, K. Tagawa, and K. Yamanaka, "Ion exchanging zeolite with a silver compound," US Patent no. 4911898, 1990.

[85] S. Gurunathan, K.-J. Lee, K. Kalishwaralal, S. Sheikpranbabu, R. Vaidyanathan, and S. H. Eom, "Antiangiogenic properties of silver nanoparticles," Biomaterials, vol.30, no. 31, pp. 6341-6350, 2009.

[86] D. Martins, L. Frungillo, M. C. Anazzetti, P. S. Melo, and N. Durán, "Antitumoral activity of L-ascorbic acid-poly-D, L-(lactide-co-glycolide) nanoparticles containing violacein," International Journal of Nanomedicine, vol. 5, no. 1, pp. 77-85, 2010.

[87] P. Yu, V. L. Blagoi, G. O. Galkin, and Gladchenko, Metallokompleksy Nukleinovykh Kislot v Rastvorakh, Naukova Dumka, Kiev, Ukraine, 1991.

[88] S. Gurunathan, J. Raman, S. N. Abd Malek, P. A. John, and S. Vikineswary, "Green synthesis of silver nanoparticles using Ganoderma neo-japonicum Imazeki: a potential cytotoxic agent against breast cancer cells," International Journal of Nanomedicine, vol. 8, pp. 4399-4413, 2013.

[89] M. I. Sriram, S. B. M. Kanth, K. Kalishwaralal, and S. Gurunathan, "Antitumor activity of silver nanoparticles in Dalton's lymphoma ascites tumor model," International Journal of Nanomedicine, vol. 5, no. 1, pp. 753-762, 2010.

[90] P. V. AshaRani, G. L. K. Mun, M. P. Hande, and S. Valiyaveettil, "Cytotoxicity and genotoxicity of silver nanoparticles in human cells," ACS Nano, vol. 3, no. 2, pp. 279-290, 2009. 

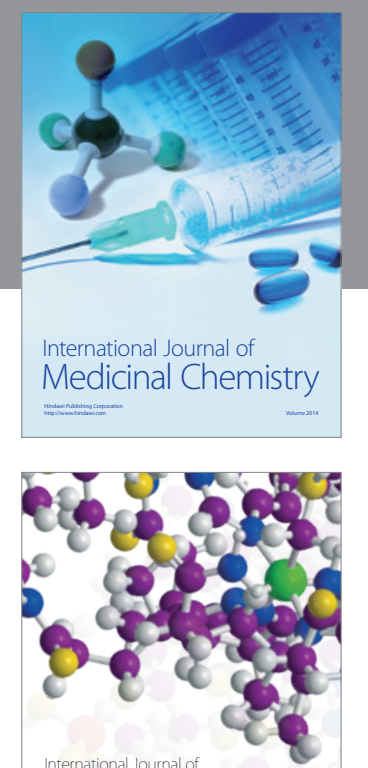

\section{Carbohydrate} Chemistry

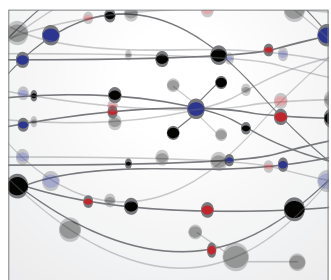

The Scientific World Journal
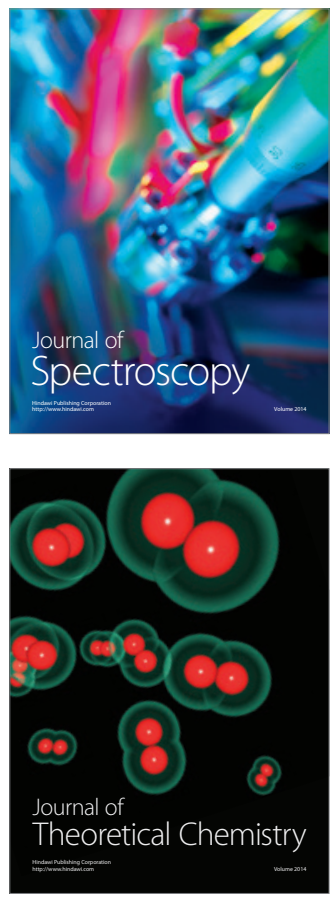
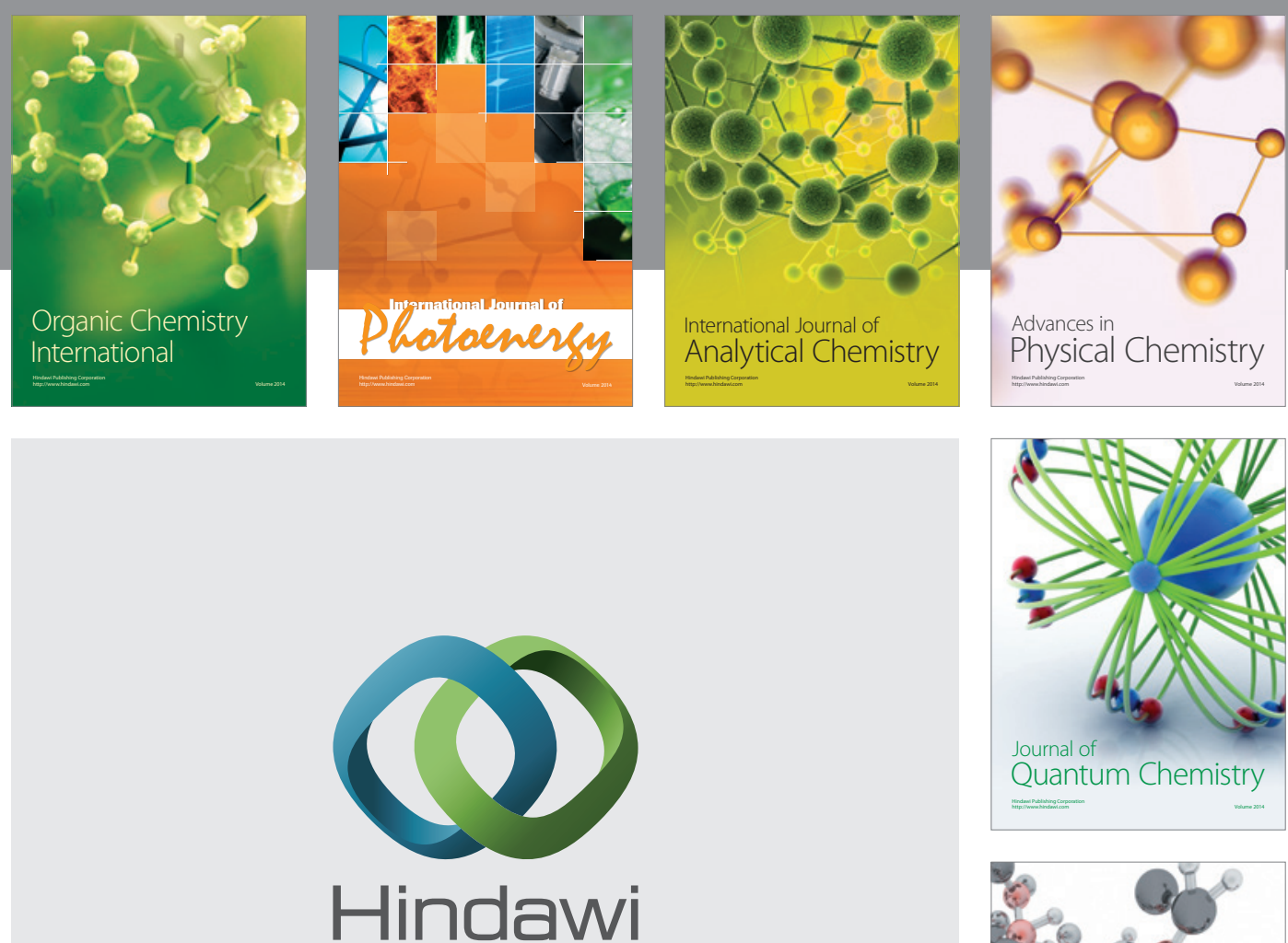

Submit your manuscripts at

http://www.hindawi.com

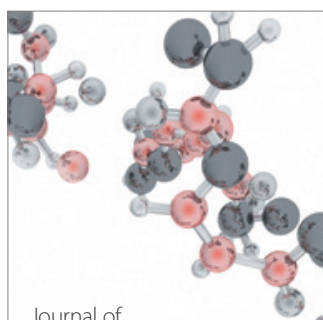

Analytical Methods

in Chemistry

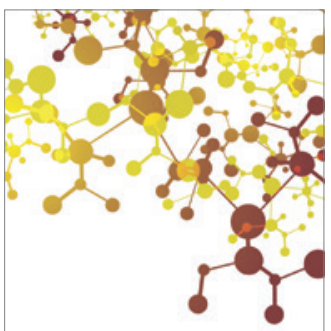

Journal of

Applied Chemistry

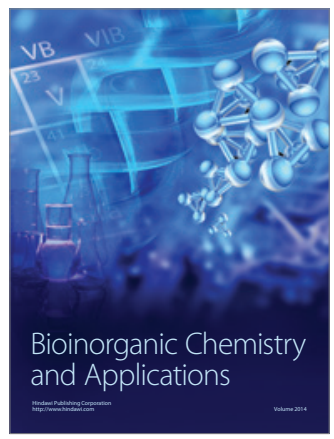

Inorganic Chemistry
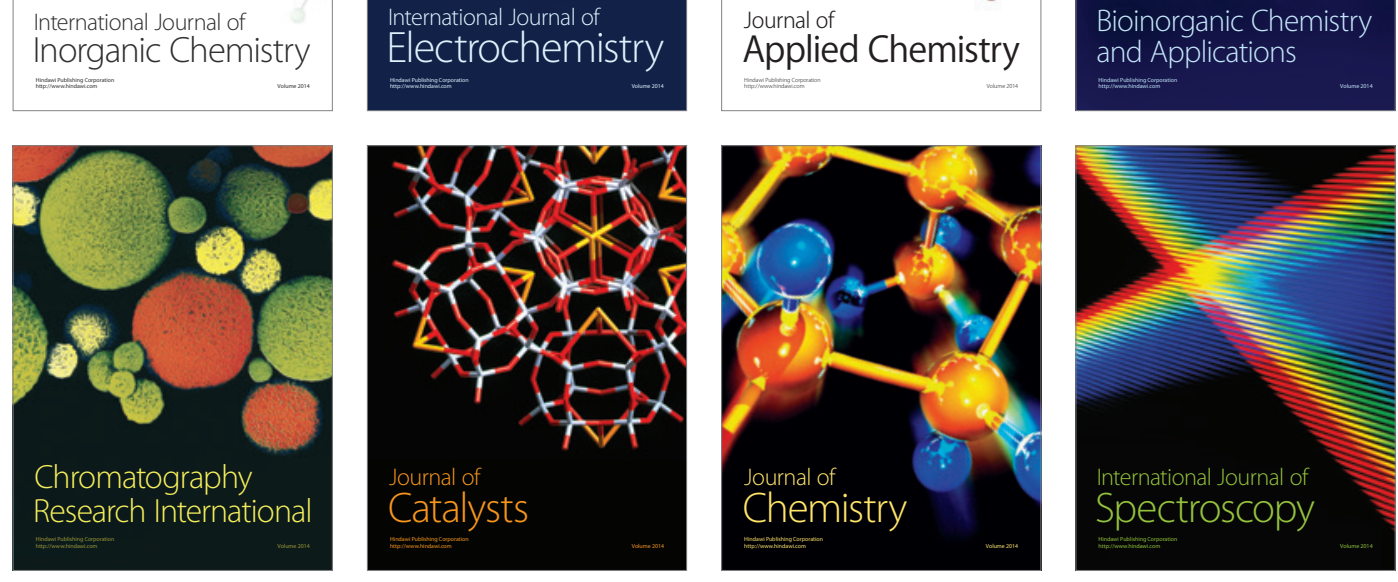